\title{
Microbial deterioration of stored water for users supplied by stand-pipes and ground-tanks in a peri-urban community
}

\author{
S Maraj', N Rodda"*, S Jackson ${ }^{1,2}$, C Buckley ${ }^{3}$ and N Macleod ${ }^{4}$ \\ ${ }^{1}$ Pollution Research Group, School of Biological and Conservation Sciences, University of KwaZulu-Natal, Durban 4041, South Africa \\ ${ }^{2}$ eThekwini Municipality, Water and Sanitation, Halifax Road, Pinetown 3600, South Africa \\ ${ }^{3}$ Pollution Research Group, School of Chemical Engineering, University of KwaZulu-Natal, Durban 4041, South Africa \\ ${ }^{4}$ eThekwini Municipality, Water and Sanitation, 6 Prior Road, Durban 4001, South Africa
}

\begin{abstract}
Two forms of water service delivery in peri-urban settlements in the eThekwini municipal region are communal stand-pipes and household ground-tanks. Water from these sources requires storage prior to use. Previous studies have shown that water quality tends to deteriorate during storage. This study was conducted during the winter season and tested water from standpipe and ground-tank households for deterioration of microbial quality relative to source. Thirty stand-pipe and 27 groundtank households were sampled for a period of $10 \mathrm{~d}$. Samples were tested for total organisms, total coliforms, Escherichia coli, conductivity, turbidity, $\mathrm{pH}$ and free and total chlorine. Households were divided into groups on the basis of the age distribution of members to assess the impact of household composition on stored water quality. Stand-pipe households were further divided according to the type of water containers used. Results indicated that both ground-tank and stand-pipe water deteriorated during storage although ground-tank water was of better quality than stand-pipe water. There was no significant difference in water quality between stand-pipe households that used open-top containers and those that used closed-top containers. Comparison of the water quality relative to age distribution of households showed that householders were at increased risk of consuming faecally contaminated water if children were present in the case of households supplied by ground- tanks, but not for those supplied by stand-pipes. Results from stand-pipe households with adults only indicated that such households maintained better personal hygiene but lower container hygiene than those households consisting of children, whereas the opposite effect was seen in those stand-pipe households with children present.
\end{abstract}

Keywords: drinking water quality, stored water, stand-pipes, ground-tanks, E. coli, total coliforms

\section{Introduction}

It is a basic human right for every individual to be provided with a supply of potable water. The South African government introduced the free basic water policy in 1994 in order to supply poor communities with potable water. The city of Durban, KwaZuluNatal, is provided with water by the eThekwini Municipality at four service levels: public stand-pipes, ground-tanks, roof tanks, and in-house full pressure taps.

Stand-pipes and ground-tanks represent the two lowest levels of water supply in Durban (Brocklehurst, 2002) and are encountered in informal and low-income peri-urban communities. Water received via such sources requires storage prior use. Numerous studies from several countries have indicated that it is during this period of collection and storage that the microbiological and physico-chemical quality of water may deteriorate to levels unsafe for human consumption (Genthe et al., 1997; Jagals et al., 1997; Jenssen et al., 2002; Bailey and Archer, 2004; Gundry et al., 2004; Jagals et al., 2004; Wright et al., 2004; Trevett et al., 2005).

Various reasons have been proposed for the deterioration of water quality between the source and point-of-use. The hygienic

This paper was originally presented at the 2006 Water Institute of South Africa (WISA) Biennial Conference, Durban, South Africa, 21-25 May 2006.

* To whom all correspondence should be addressed.

I뇨+2731 260-3015/260-3192; fax:+2731 260-2029;

e-mail: roddan@ukzn.ac.za condition of the water storage containers and the environment in which these containers are stored are believed to be major factors leading to the deterioration of stored water (Jagals et al., 1999; Gundry et al., 2004; Jagals et al., 2004; Trevett et al., 2005). Studies have shown that water stored in open-top buckets is of lower microbiological water quality than water stored in screwtop closed containers (Jagals et al., 1997). Uncovered containers are exposed to environmental conditions, such as dust and dirt, which may contribute to the deterioration in water quality (Jagals et al., 1997; Jagals et al., 1999; Wright et al., 2004; Trevett et al., 2005) Storage containers placed on the floor may be more likely to be contaminated by animals or children than containers placed on an elevated surface, e.g. on a table or chair (Jensen et al., 2002). Studies have suggested that the vessels used to remove water from the storage container may also contribute to the microbiological deterioration of water quality (Jagals et al., 1997; Jagals et al., 1999; Trevett et al., 2005). Water stored in open-top containers appears more likely to become contaminated by unhygienic vessels than screw-cap closed containers, which do not require the use of such vessels (Jensen et al., 2002; Trevett et al., 2005).

Areas provided with water by stand-pipes or ground-tanks are also less likely to have adequate sanitation provision (Genthe and Seager, 1996). Poor sanitation is likely to affect the health status of community members, particularly pre-school age children. Combined with poor hygiene, such as lack of handwashing or use of a common source of stored water for washing, this means that stored drinking water could become faecally contaminated and may contribute to the spread of diseases such as cholera, hepatitis A, hepatitis E, typhoid, dysentery and 
gastrointestinal infection (Genthe and Seager, 1996; Zamxaka et al., 2004).

Diarrhoea is a symptom of many of these waterborne diseases and, whilst not all cases of diarrhoea are related to water, it can be used as an indicator of contaminated water. It is difficult to directly link cases of diarrhoea to water contamination (Bailey and Archer, 2004; Zamxaka et al., 2004). A case study done by Bailey and Archer (2004) showed a link between diarrhoea and hygiene behaviours in relation to water, but other studies have found no correlation between Escherichia coli levels in water and incidences of childhood diarrhoea and gastroenteritis (Gundry et al., 2004; Jensen et al., 2004).

Waterborne diseases place a heavy health burden on rural and peri-urban communities in developing countries such as South Africa, where there are an estimated 24 million cases of diarrhoea annually (Obi et al., 2003; Bailey and Archer, 2004). Providing potable water to such communities may help alleviate this burden, but deterioration of water quality during storage may eliminate much or all of the potential benefit. Water quality testing is the only way to establish whether this is true for a given community, and hence whether additional health and hygiene education campaigns or other interventions are required.

It is not possible to test drinking water samples for every waterborne pathogen, and detection techniques are often expensive as well as time-consuming (Grabow, 1996). For this reason, indicator organisms are used to test water for potential contamination by pathogens. Indicator organisms are chosen according to certain requirements, some of which are:

- Indicator must be present when the pathogen is present

- Indicator must be as resistant to the environmental conditions, water purification and disinfection processes as the pathogen

- Indicator must be non-pathogenic

- Indicator must be detectable by relatively simple, rapid laboratory techniques (Grabow, 1996).

In most studies, more than one indicator organism is used, as there is no single indicator micro-organism that adequately indicates resistance to treatment processes or that can mimic the environmental behaviour of all classes of pathogens (bacteria, protozoan parasites, helminthic parasites, viruses) (Genthe and Seager, 1996; Grabow, 1996)

Heterotrophic plate count bacteria are used as indicators of the general microbiological water quality (Genthe and Seager, 1996; Grabow, 1996; Nala et al., 2003). Water samples may also be tested for total coliform bacteria in order to assess the general hygienic quality of water, which may also indicate the presence of pathogens responsible for the transmission of waterborne diseases (Genthe and Kfir, 1995; Genthe and Seager, 1996; Grabow, 1996; Zamxaka et al., 2004). E. coli are used to test for faecal contamination of drinking water (Genthe and Kfir, 1995; Genthe and Seager, 1996; Jensen et al., 2004; Wright et al., 2004). Somatic coliphages are frequently used as indicators of the presence of enteric viruses (Genthe and Kfir, 1995).

Pilot studies undertaken in a peri-urban community in Durban, KwaZulu-Natal, South Africa, by Arjun et al. (2004) were unable to find statistically significant differences between source water quality and point-of-use water quality in stand-pipe and ground-tank households. The sample sizes of both ground-tank and stand-pipe households were too small to show statistically significant differences, although general trends could be observed. On the basis of these studies, a larger study in the same community was conducted, aimed at sampling sufficient households to achieve statistically valid comparisons and to test the effect of household demographics on water quality.

A comparison of the water quality between the source (piped water, stand-pipe) and point-of-use (ground-tank, storage containers for stand-pipe households) was conducted to determine if microbiological deterioration occurred relative to the source. Ground-tank and stand-pipe households were further separated according to age of household members in order to determine the effect on stored water quality. Stand-pipe groups were additionally divided into households that transported and stored water in closed-top containers and households that transported or stored water in open-top containers. The study reported here presents results for the 2005 winter season. A further summer study is presently in progress.

\section{Materials and methods}

\section{Study site}

This study was carried out in a peri-urban area in Cato Manor, Durban. Twenty-seven ground-tank households and 30 standpipe households were sampled once a day for a period of $10 \mathrm{~d}$ per household during June and July 2005. Four stand-pipes in the sample area were taken as representatives of source water, as supplied to stand-pipe households. Since ground-tank households are supplied with water from the municipal distribution system, water samples from the eThekwini laboratory were taken as indicative of water quality at source for these consumers.

\section{Sampling}

Water samples were collected from the ground-tanks, storage containers, and sources into sterile glass bottles containing 3 to 4 drops of $3 \%$ sodium thiosulphate in order to neutralise any residual chlorine. Free and total chlorine was tested in the field whilst an additional water sample was collected for $\mathrm{pH}$, conductivity, and turbidity tests. Water samples were stored on ice and transported to the eThekwini laboratory for microbiological and physico-chemical analyses within $20 \mathrm{~h}$.

\section{Sample grouping}

Stand-pipe households were divided into groups depending on the type of storage containers used to transport and store drinking water. Households were classified into one of two groups: households that transported and stored drinking water in closedtop containers, and households that either transported or stored water in open-top containers. Stand-pipe and ground-tank households were additionally divided into sub-groups based on the household age distribution as follows: households that had 3 or fewer children under the age of 5 years, households with children between the ages of 6 and 17 years, and households that consisted of adults only.

\section{Analyses}

Standard methods, as documented eThekwini municipal laboratories, were used for all microbiological analyses. Water samples were tested for heterotrophic plate count bacteria by a standard pour plate method using a non-selective agar (eThekwini Water and Sanitation, 2004a). Total coliform bacteria and E. coli were tested by membrane filtration and incubation of filters on Chromocult ${ }^{\circledR}$ coliform agar (Merck). Colonies were identified by 


\begin{tabular}{|c|c|c|l|}
\hline \multicolumn{4}{|c|}{ Summary of DWAF guidelines for domestic water use for total organisms, total coliforms and E. coli } \\
(adapted from DWAF, 1996)
\end{tabular}

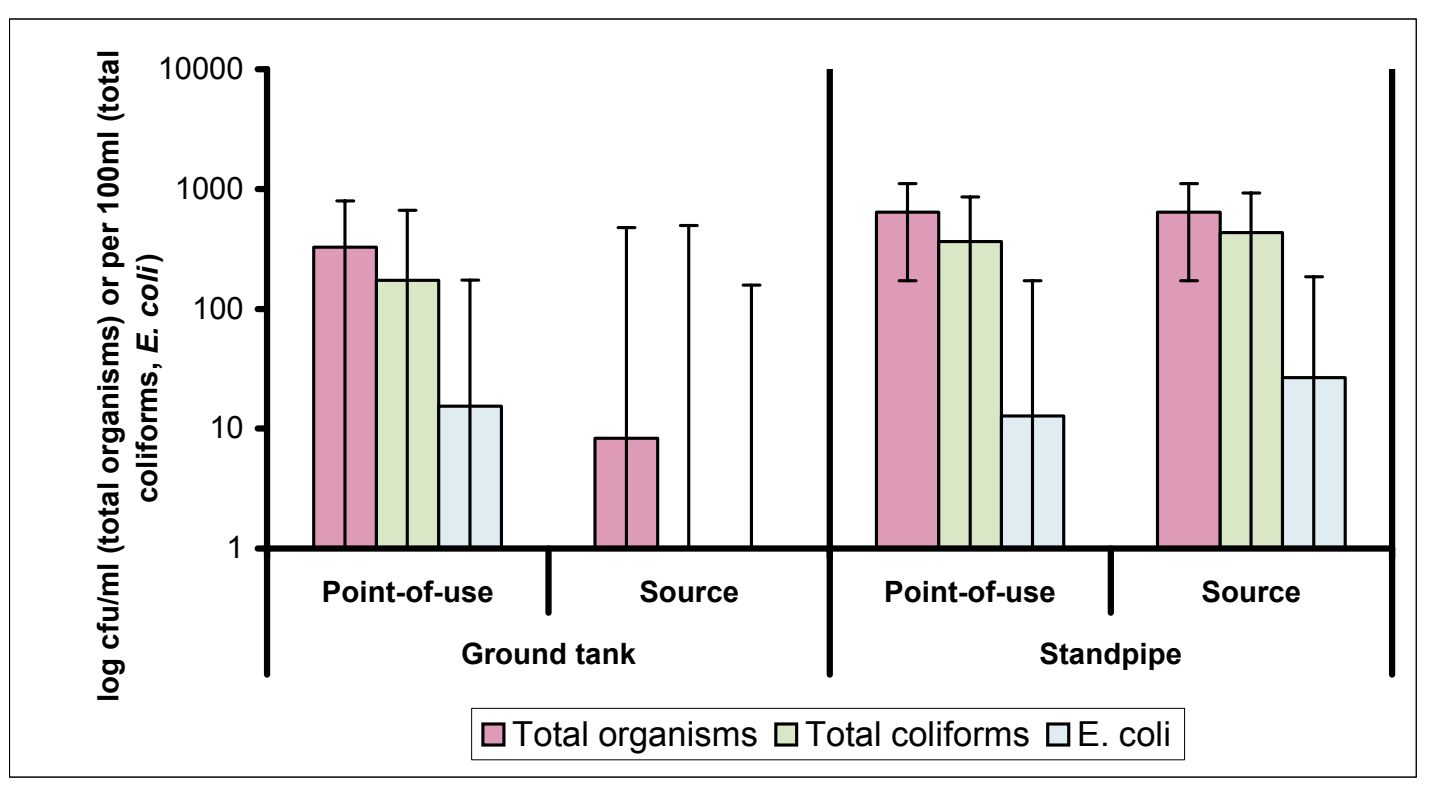

Figure 1

Mean microbial counts at source and point-of-use for ground-tank and stand-pipe households. Error bars indicate $95 \%$ confidence intervals.

colour (eThekwini Water and Sanitation, 2004b). Water samples were also tested for $\mathrm{pH}$, turbidity and conductivity at the eThekwini laboratory. Heterotrophic plate counts were expressed as $\mathrm{cfu} / \mathrm{m} \ell$ of sample, and total coliforms and E. coli as cfu/ $100 \mathrm{~m} \ell$ of sample. Turbidity was expressed as nephelometric turbidity unit (NTU), conductivity as $\mathrm{mS} / \mathrm{m}$, and free and total chlorine as $\mathrm{mg} \mathrm{Cl} / \ell$.

\section{Statistics}

Microbiological data tends to show considerable variation, with a relatively larger number of low numbers and non-detect values and few instances of high counts. This pattern typically takes the form of a log-normal distribution. To allow parametric statistical tests to be used, 1 was added to all values and the $\log _{10}$ of data taken. Data, including the log-transformed microbial data, were tested for normality of distribution by the Kolmogrov-Smirnov test. Significance of differences among groups was evaluated by one-way ANOVA with post-hoc testing. The independent student's t-test was used to test for differences between openand closed-top container groups for stand-pipe households, and between the source and point-of-use water samples, for both ground-tank and stand-pipe water samples. Significance was taken at the $\mathrm{p}<0.05$ level ( $95 \%$ confidence level).

\section{Results}

The Department of Water and Forestry guidelines for domestic use of water are given in Table 1.

In the stand-pipe user group, mean microbial levels were similar at source and at point-of-use, and were actually higher at the source in the case of total coliforms and E. coli. However, the differences were not statistically significant (Fig. 1). This indicates that the quality of water at source for stand-pipes is poor. Comparison with Table 1 shows that both source and point-of-use water posed a potential to substantial risk of microbial infection to consumers. Among the physico-chemical variables measured, free and total chlorine were significantly lower at point-of-use than at source.

In the total ground-tank user group, there were significant differences between source and point-of-use for total organisms $(\mathrm{p}=0.000)$ and total coliforms $(\mathrm{p}=0.000)$, but not for E. coli $(\mathrm{p}=0.705)$ (Fig. 1). In all cases, mean microbial counts were higher in water at point-of use than at source. Comparison of mean microbial counts at point-of-use with those in Table 1 reveals that ground-tank water at point-of-use posed a potential risk of microbial infection in consumers.

There were significant differences between the point-of-use water quality for ground-tank households and stand-pipe house- 


\begin{tabular}{|c|c|c|c|c|c|}
\hline \multicolumn{6}{|c|}{$\begin{array}{c}\text { TABLE } 2 \\
\begin{array}{c}\text { Averages of physico-chemical measurements for ground-tank and stand-pipe demographic } \\
\text { groups }\end{array}\end{array}$} \\
\hline Group & $\begin{array}{c}\text { Free Cl } \\
(\mathrm{mg} \mathrm{Cl} / \mathrm{\ell})\end{array}$ & $\begin{array}{c}\text { Total Cl } \\
(\mathrm{mg} \mathrm{Cl} / \mathrm{l})\end{array}$ & $\mathrm{pH}$ & $\begin{array}{c}\text { Turbidity } \\
\text { (NTU) }\end{array}$ & $\begin{array}{c}\text { Conductivity } \\
(\mathrm{mS} / \mathrm{m})\end{array}$ \\
\hline Ground-tank: children $<5$ years & 0.38 & 0.57 & 8.00 & 0.61 & 14.92 \\
\hline Ground-tank: children 6-17 years & 0.36 & 0.54 & 8.01 & 0.63 & 14.90 \\
\hline Ground-tank: adults only & 0.41 & 0.60 & 8.01 & 0.70 & 14.91 \\
\hline Stand-pipe: children $<5$ years & 0.25 & 0.38 & 7.91 & 1.41 & 15.53 \\
\hline Stand-pipe: children $6-17$ years & 0.25 & 0.38 & 7.92 & 1.12 & 15.43 \\
\hline Stand-pipe: adults only & 0.19 & 0.31 & 7.94 & 0.76 & 15.29 \\
\hline
\end{tabular}

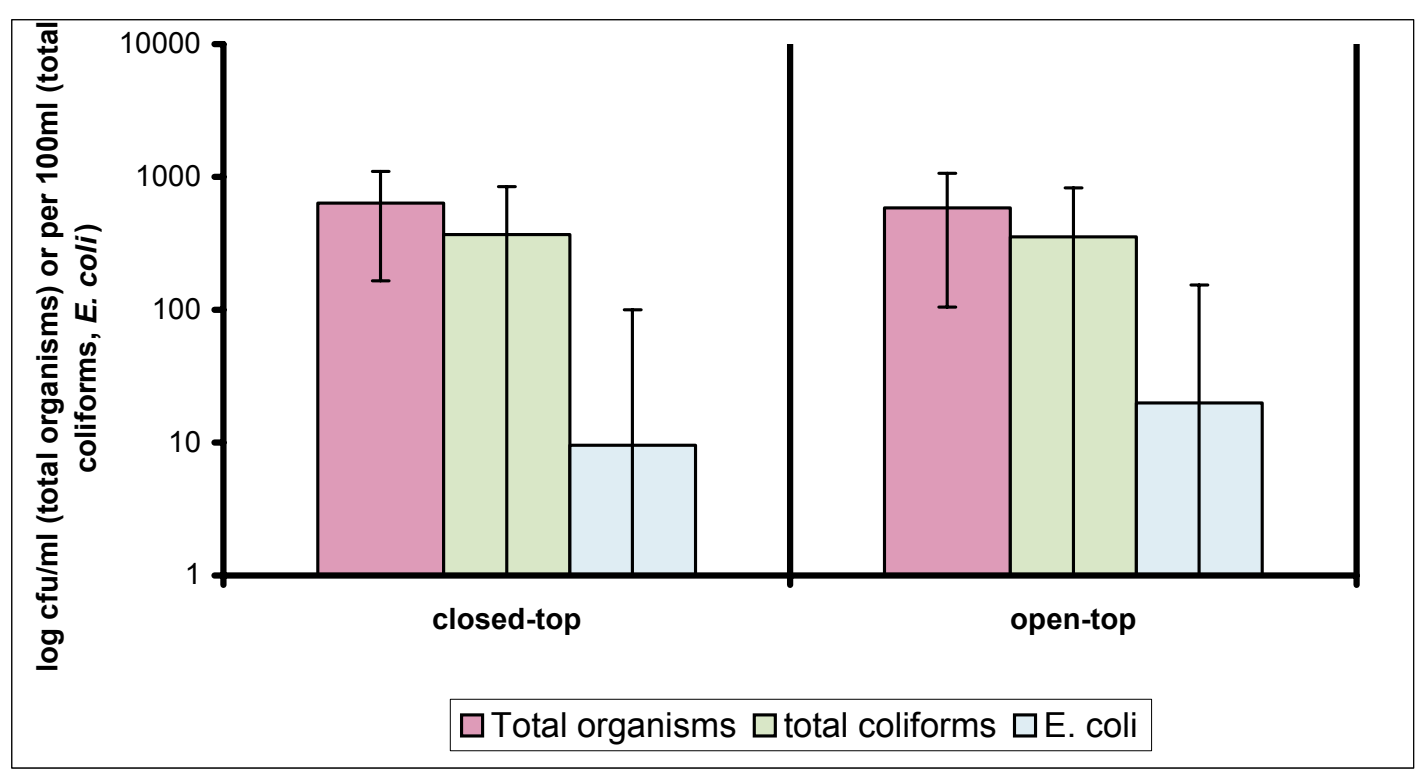

Figure 2

Mean microbial levels between stand-pipe households using open-top or closed-top containers. Error bars show $95 \%$ confidence intervals

holds. Total organisms and total coliforms were significantly lower for ground-tank households than stand-pipe households ( $\mathrm{p}=0.00$ for both). E. coli levels were slightly, but significantly, higher for ground-tank households than stand-pipe households $(\mathrm{p}=0.00)$.

The total organism, total coliform, and E. coli levels were slightly higher in those stand-pipe households that either transported or stored water in an open-top container, than in those using a closed-top container. However, these differences were not significant (Fig. 2).

There were no significant differences among total organisms, total coliforms, total chlorine, $\mathrm{pH}$, turbidity and conductivity for the age group distributions monitored among ground-tank households. E. coli levels were markedly lower in households of adults only than in households including children. (Fig. 3; Table 2). A significant difference was observed among free chlorine levels measured in households with adults only and households with children between the ages of 6 to 17 years $(p=0.026)$.

Among stand-pipe households, total organism and total coliform levels were similar, but slightly higher for households that consisted of adults only when compared to the other age distributions (Fig. 3, Table 2). On the other hand, E. coli levels were markedly higher for households including children than for households of adults only. There were significant differences in total organism levels $(p=0.023)$, free and total chlorine $(p=0.021$ and $\mathrm{p}=0.015$ respectively), and turbidity $(\mathrm{p}=0.003)$ between stand-pipe households that consisted of children under the age of 5 years, and those with adults only. The average microbial and physico-chemical levels in stand-pipe households with children under the age of 5 years, and those with children between the ages of 6 to17 years, were similar, but there was a significant difference between the total chlorine levels among these groups $(\mathrm{p}=0.010)$.

\section{Discussion}

Water from ground-tanks deteriorated in quality during storage. Total organism levels at the point-of-use for ground-tank households fell into the range of $100-1000 \mathrm{cfu} / \mathrm{m} \ell$. According to DWAF guidelines (DWAF, 1996), such levels present a potential risk of microbial infection, with the risk of infection increasing with increased consumption of water. The total coliform levels at the point-of-use for the ground-tank households were greater than $100 \mathrm{cfu} / 100 \mathrm{~m} \ell$. High total coliform levels indicate that there is a substantial risk of microbial infection with increased exposure to contaminated water. The major factor contributing to the low water quality in ground-tanks is likely to be the condition and age of the tanks. The ground-tanks that were in use at the households sampled in Cato Manor were between 6 and 10 years old, and most were in poor condition. During the sampling 


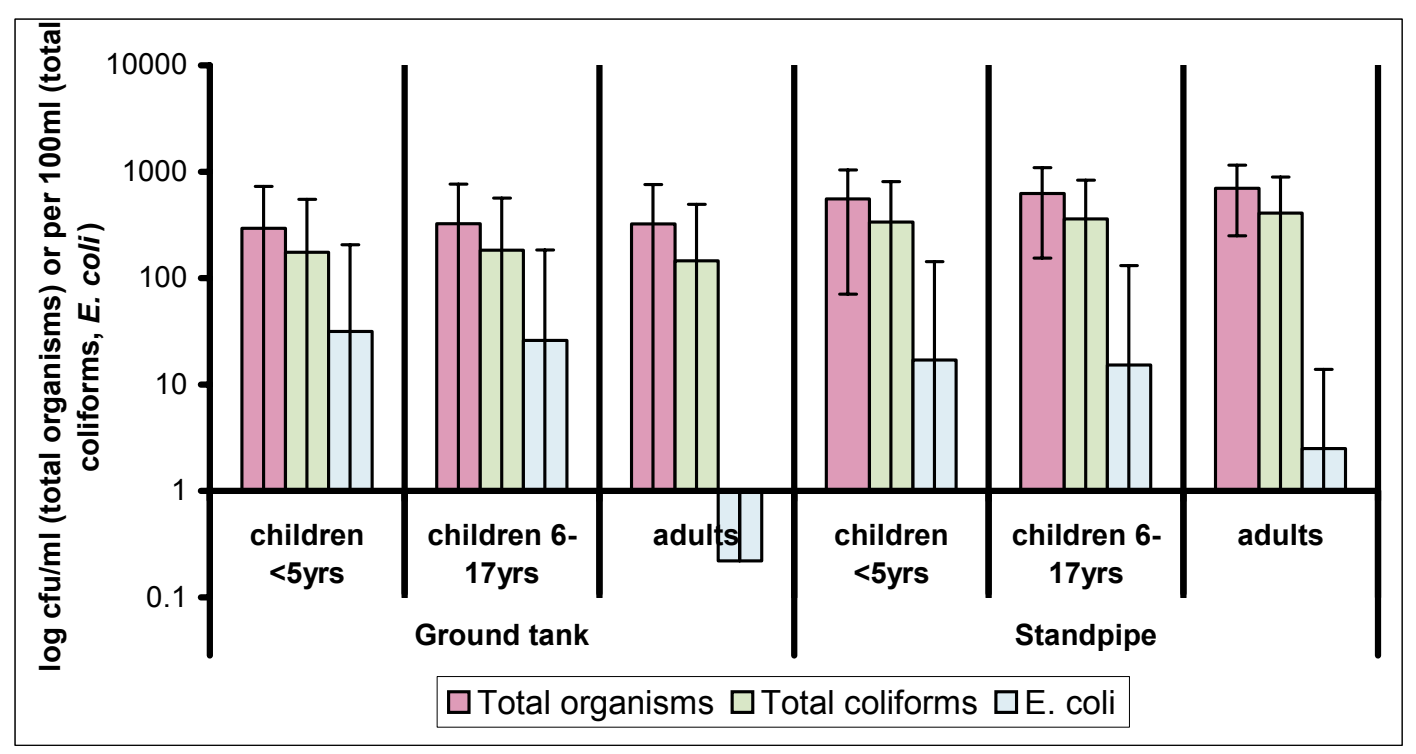

Figure 3

Mean microbial levels for the ground-tank and stand-pipe households, differentiated by age distribution of household members. Error bars show $95 \%$ confidence intervals.

period, it was noted that many of the of the ground-tank lids were not fitted correctly over the tank, allowing dirt, dust and sand to enter the tank, especially during heavy rains, thereby contributing to the deterioration of the water quality. Biofilm formation on the inner walls of the ground-tanks may also play a role in the deterioration of water quality, since.

Among the stand-pipes and stand-pipe households sampled, mean microbial counts both at the source and at point-of-use exceeded the recommended levels for domestic use of water. Four stand-pipes in the area were sampled as representing the source for stand-pipe households. One stand-pipe, in particular, consistently yielded water with high microbial counts. This may have been due to location of that stand-pipe, which was observed to be in continuous use by taxi operators, was held together by a piece of cloth tied around the nozzle, and was used during on-site washing of clothes. All these activities are likely to have contributed to high microbial levels at the stand-pipe source. It is possible that the high microbial levels from stand-pipe households at the point-of-use may have been due to contamination not just at the point-of-use but also during collection and storage, although the difference between quality at source and at point-of-use was not significant. The lower free and total chlorine levels seen at the point-of-use for stand-pipe households indicated that water had been stored for a period of time sufficient to allow residual chlorine in the water to dissipate. Lowered chlorine levels are less effective against micro-organisms than chlorine residuals at the levels stated in the guidelines.

Both ground-tank and stand-pipe water at point-of-use deteriorated during storage (i.e. relative to the source) in this winter study. Although the water from ground-tank households was microbially unsuitable for consumption on the basis of DWAF guidelines, it was of better quality than the point-of-use quality of water obtained from stand-pipes and subsequently stored. This is contradictory to the results obtained from the pilot study of Arjun et al. (2004) where results indicated that the stand-pipe water at point-of-use was of better quality than ground-tank point-of-use water in winter. The larger sample size used in the present study may be responsible for the dissimilar results, in which case greater confidence should be placed in the more representative study with larger sample numbers.

It has previously been reported that the type of containers used to store or transport water (i.e. closed-top or open-top) may contribute to the deterioration of stored water quality (Jagals et al., 1997; Jagals et al., 1999; Wright et al., 2004; Trevett et al., 2005). This argument was not supported by the present study, in which neither the microbial nor the physico-chemical factors investigated were affected by the type of container used to transport or store water. All of the households that participated in the study, with the exception of one, indicated that the container used to collect water was the same container used to store water. Hence additional contamination could not have occurred during the transfer of water from containers.

Ground-tank householders have no direct contact with the water whilst it is stored within the tank so the age distribution of household members seems unlikely to influence water quality. However, water collected from ground-tank households that included children under the age of 5 years tested positive for the presence of $E$. coli on numerous occasions This indicates that households including young children are at a higher risk of contaminating the water with faecal matter. The source of contamination may be that soiled nappies (or soiled children) are washed directly at the ground-tank, that toilets are close to the ground-tanks, and that young children touch the tap or surrounding parts of the ground-tank with faecally contaminated hands.

The stand-pipe households consisting of adults only had higher total organism and total coliform levels (although not significantly so), but lower $E$. coli levels than the other age groups, indicating that those households with adults only may have a better understanding of proper personal hygiene than households with children (lower faecal contamination), but show lower container hygiene (higher environmental contamination). This maybe a result of lower levels free and total chlorine in water from these households compared to the households with children present. The lower free and total chlorine levels are possibly due to the storage of water for longer periods of time. These households tend to be smaller in size compared to house- 
holds with children. They may therefore replace water in storage vessels less frequently or store large volumes of water, thereby providing greater opportunity for residual chlorine to dissipate and for contamination of water from environmental conditions such as dust, flies or frequent contact.

The higher $E$. coli levels seen water from households that included of children is likely to reflect lower personal hygiene typical of young children. Thus the presence of children appears to represent a risk factor for contamination of stored water. Many households allow children to collect water from the standpipe and to remove water stored within the household. The turbidity of water in those stand-pipe households which included children exceeded the DWAF guidelines for the domestic use of water (DWAF, 1996). The turbidity levels are dependent on the amount of suspended particles present in the water. Suspended particles act as a substrate for micro-organisms in the water, thus promoting growth of the micro-organism populations.

Finally, an unexpected limiting factor in recruiting households for participation in this study was the high number of households using illegal water connections which provided water in addition to the free basic minimum volume, at no extra cost. (Illegal connections were an exclusion criterion in selection of households). Community members claim to use illegal connections due to the assumed better quality of water from such sources. Many households have turned these illegal water connections into yard or indoor taps. Future studies should include the testing of water directly from these sources (illegal water connections) and at the point-of-use, and social investigation into the perceived needs which motivate consumers to tamper with municipal water connections.

\section{Conclusions}

- Poor water quality at source for users supplied by communal stand-pipes emerged as a clear cause for concern, particularly if stand-pipes are heavily used for a variety of purposes. This indicates the need for improved education on the importance of cleanliness and hygiene at the standpipes themselves and in the immediate vicinity thereof. The provision of good drainage to minimise contamination by splashing and pooling of water, and regular inspection to ensure that stand-pipes are in good order and not operated incorrectly (e.g. tied open to provide continuous flow) are other possible management interventions.

- The possibility of contamination of water during storage in ground-tanks as a result of the poor condition of the tanks and of growth of biofilm on the inner walls of the tanks warrants further investigation.

- Contrary to expectation, the type of container used to collect and store water had no discernible impact on the quality of water at point-of-use for users supplied by stand-pipes.

- The age-distribution of the household did have a significant effect on the quality of stored water. The presence of young children in the household was a strong risk factor for faecal pollution of water, indicating a need for improved health and hygiene education of children in pre-schools and schools, and of care-givers through community health education programmes.

- In households with adults only, there appeared to be a greater risk of environmental contamination of stored water, suggesting that community members should be educated regarding storage of water, e.g. addition of bleach to ensure a chlorine residual during storage.

- The social pressures leading to high incidence of illegal water connections, and the effect thereof on point-of-use water quality, should be investigated further.

\section{Acknowledgements}

Ethekwini Municipality is thanked for funding, as well as analytical and logistical support of this project.

\section{References}

ARJUN N, JOUBERT J-P, SMITH M, RODDA N, and BUCKLEY C (2004) Water quality at point-of-use for users supplied by stand-pipes and ground-tanks in a peri-urban community. Paper presented at IWA Specialist Group Conference on Water and Wastewater Management for Developing Countries, Victoria Falls, Zimbabwe.

BAILEY I W and ARCHER L (2004) The impact of introducing treated water on aspects of community health in a rural community in KwaZulu-Natal. Water Sci. Technol. 50 (1) 105-110.

BROCKLEHURST C (2002) Durban Metro Water: Private Sector Partnerships to serve the Poor. Water and Sanitation Program - Africa.http://www.wsp.org/publications/af durban.pd (Accessed on $10 / 03 / 2005$ )

DEPARTMENT OF WATER AFFAIRS AND FORESTRY (DWAF) (1996) South African Water Quality Guidelines Vol. 1: Domestic Use. Pretoria.

ETHEKWINI WATER AND SANITATION (2004a) Test Method No. MM007, Heterotrophic plate count. eThekwini Waste Water Laboratory, Durban.

ETHEKWINI WATER AND SANITATION (2004b) Test Method No. MM002, Analysis of total coliform and E. coli on chromocult medium using the membrane filter procedure. eThekwini Water Services Waste Water, Laboratory, Durban.

GENTHE B and KFIR R (1995) Studies on Microbiological Drinking Water Quality Guidelines. WRC Report No. 469/1/95. Water Research Commission, Pretoria, South Africa.

GENTHE B and SEAGER J (1996) The Effect of Water Supply, Handling and Usage on Water Quality in Relation to Health Indices in Developing Communities. WRC Report No. 562/1/96. Water Research Commission, Pretoria, South Africa

GENTHE B, STRAUSS N, SEAGER J, VUNDULE C, MAFORAH F and KFIR R (1997) The effect of type of water supply on water quality in a developing community in South Africa. Water Sci. Technol. 35 (11-13) 35-40.

GRABOW WOK (1996) Waterborne diseases: Update on water quality assessment and control. Water SA 22 (2) 193-201.

GUNDRY S, WRIGHT J and CONROY R (2004) A systematic review of the heath outcomes related to household water quality in developing countries. J. Water and Health 2 (1) 1-13.

JAGALS P, GRABOW WOK and WILLIAMS E (1997)The effects of supplied water quality on human health in an urban development with limited basic subsistence facilities. Water SA 23 (4) 373-378.

JAGALS P, BOKAKO TC and GRABOW WOK (1999) Changing consumer water use patterns and their effect on microbiological water quality as a result of an engineering intervention. Water $S A 25$ (3) 297-300.

JAGALS P, NALA NP, TSUBANE TJ, MOABI M and MOTAUNG KC (2004) Measuring changes in water-related and hygiene practices by developing community households. Water Sci. Technol. 50 (1) 91-97.

JENSEN PK, ENSINK JHJ, JAYASINGHE G, VAN DER HOEK W, CAIRNCROSS S and DALSGAARD A (2002) Domestic transmission routes of pathogens: the problem of in-house contamination of drinking water during storage in developing countries. Trop. Med. Health 7 (7) 604-609

JENSEN PK, JAYASINGHE G, VAN DER HOEK W, CAIRNCROSS $S$ and DALSGAARD A (2004) Is there an association between bacteriological drinking water quality and childhood diarrhoea in developing countries? Trop. Med. Internat. Health 9 (11) 1210 1215 . 
NALA NP, JAGALS P and JOUBERT G (2003) The effect of a waterhygiene educational programme on the microbiological quality of container-stored water in households. Water SA 29 (2) 171-176.

OBI CL, POTGIETER N, BESSONG PO and MATSAUNG G (2003) Scope of potential bacterial agents of diarrhoea and microbial assessment of quality of river water sources in rural Venda communities in South Africa. Water Sci. Technol. 47 (3) 59-64.

TREVETT AF, CARTER RC and TYRREL SF (2005) Mechanisms leading to post-supply water quality deterioration in rural Honduran communities. http://taylorandfrancis.metapress.com/index
QJECP1RY33GN3JJH.pd (Accessed on 26/08/2005).

WRIGHT J, GUNDRY S and CONROY R (2004) Household drinking water in developing countries: a systematic review of microbiological contamination between source and point-of-use. Trop. Med. Internat. Health 9 (1) 106-117.

ZAMXAKA M, PIRONCHEVA G and MUYIMA NYO (2004) Microbiological and physio-chemical assessment of the quality of domestic water sources in selected rural communities of the Eastern Cape Province, South Africa. Water SA 30 (3) 333-340. 